\title{
A Review of Armenian Proverbs from the Territory of Iranian Azerbaijan (the Salmast Dialect)
}

\begin{abstract}
In 2016 the author took part in a scientific fieldtrip of German academics to Iranian Azerbaijan. There he received two books devoted to the Armenian dialect of the town Salmast. One of them was a collection of about 800 proverbs in this dialect spoken in the past near a town located to the north-west of Lake Urmia (Orumiye). The present publication gives English translation of about 50 proverbs of the Salmast dialect.
\end{abstract}

Keywords: Armenian dialectology, Armenians in Iran, proverbs

In mid April 2016 I took part in a scientific fieldtrip of German academics to Iranian Azerbaijan. The twelve-person group under the direction of Mr. Ishkhan Chiftjian, a lecturer in West Armenian at the University of Hamburg, visited among other things sacral monuments including the sacred Christian and Islamic monuments of two provinces (ostân) of north west Iran: West Azerbaijan (capital: Orumiye $<$ Urmia) and the East (capital: Tabriz). West Azerbaijan is former Persian Armenia (in Armenian: Parsk-a-hayk ${ }^{h}$ ), a territory lying on the south-eastern borderlands of ancient Armenia. Well known and often visited are the two historic Armenian churches there: the Church of St Thaddaeus and the Church of St Stephanos; according to the Lonely Planet Travel Survival Kit, both with traditions going back to the first century when Armenia was still pagan.

For a week in Tabriz we were the guests of the bishop of the Diocese of the Armenian Apostolic Church, Krikor Chiftjian, the brother of our guide, Ishkhan. We visited not only Armenian churches but also mosques and other sights worth seeing.

I received a most interesting present from Mr. Ishkhan: two publications devoted to the Armenian dialect of the town of Salmast (in Persian: Salmâs, in Armenian: Salmast), located to the north-west of Lake Urmia (Orumiye). This dialect is dying out, forced into disuse by the colloquial East Armenian used in the post-Soviet Armenian Republic (capital: Yerevan). Which is why these publications 
are so valuable. Written by Rubik Ohanian, who together with his father, Mekhak Ohanian, a teacher at the Armenian school in the village of Sarna near Salmast, they constitute many years of collecting, on the part of the pair, of proverbs in the local dialect. In order to assemble as rich a body of material as possible, he used a classic work of Armenian proverbs written by Aram Ghanalanian. ${ }^{1}$

The first of these publications is a collection of proverbs (in Armenian: arrac ' $)^{2}$ in the Salmast dialect, while the second - a glossary (barracank) ${ }^{3}$ containing an explanation of the dialect words edited in literary East Armenian. Both booklets were published in 2012 by the Tehran publishing house of the Armenian journal $\operatorname{Alik}^{h}$ (= "Wave"), which has been publishing in Iran for almost eighty years.

As we can read in the introduction written by the former Armenian bishop of Tabriz, Neshan, to this collection of proverbs published by Rubik Ohanian, in the environs of Salmast formerly there were five Armenian villages with schools and churches. And it was there the dialect was used, in which over the centuries these proverbs had been spoken and which in the $20^{\text {th }}$ century was to be written down by the Ohanians (father and son), these constituting the subject of research for the current article.

The Armenian dialect of Salmast constitutes a variant of a dialect better known as the Urmia dialect and this belongs to the so-called $-s$ group, ${ }^{4}$ different equally from the main group of dialects functioning within East Armenian (the -um group in the Republic of Armenia) as also those of West Armenian (from the territories of Turkey). It is characterised by forms of the Present Tense based on a participle containing the consonant $-s$ derived from the locative plural ending of Old Armenian = grabar. The examples are: gyinnäs em 'I know', g'innäs es 'you know's (cf literary East Armenian gitenal 'to know').

In terms of phonetics the Salmast dialect, in a way similar to the Van dialect from the areas of east southern Turkey, is characterised chiefly by the devoicing of the Old Armenian consonants $b, d, g, d z, d z$ and their palatalization, which ensures the partial preservation of the former phonological opposition dividing voiced consonants from voiceless non-aspirated consonants. And so, for example, the former initial $g a$ - is represented in Salmast by $k^{y} \ddot{a}$, cf. Old Armenian garrn 'lamb' $>$ Salmast $k^{y} \ddot{a r r}$.

The second feature characteristic for the Salmast dialect (equally present in the Van dialect) is the transfer of the initial $h->x$-, e.g. Old Armenian hayr 'father' $>$ Salmast xer.

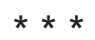

\footnotetext{
1 A. Tanalanyan, Arrac'ani, Yerevan 1960.

2 R. Ohanean, Arrac 'ani Salmast gawarri barbarrov, Tehrân 2012.

3 Idem, Barracank (barraran). Salmasti barbarr, Tehrân 2012.

4 A. Гaribyan, Hay barbarragituthyun, Yerevan 1953, pp. 342-343.

5 R. Ohanean, Barracank (barraran)..., p. 21.
} 
Rubik Ohanian's publication contains over eight hundred proverbs on 56 pages. These are ordered without any principle of classification, theme or formula. Only now and then does one get the impression that the author was motivated by some form of internal similarity for the given group of proverbs. This is the case on p. 49 of the collection (of proverbs) where one after the other a 'ditty' occurs (lines 5 and 4 from the bottom):

Korc'a vor kanoxvano monac, imaci kursvav k'inä ${ }^{6}$

'Remember that a matter put off till tomorrow is already lost.'

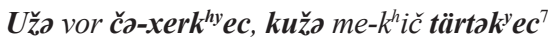

'When strength is lacking it follows to drain the pitcher a little.'

There is also no adherence within the collection to alphabetical order. In addition some of the proverbs repeat in a wholly random way.

Below the reader will find a thematic review of the material based on nearly fifty selected examples. These are cited in Latin transcript, in which aspiration is represented by ' $h$ ' in the upper fraction (e.g.: $\left.k^{h}\right)$, while palatalization by ' $y$ ' in the upper fraction (e.g.: $\left.k^{y}\right)$. The front 'a' is transcribed by $\ddot{a}$.

$$
* * *
$$

Specifically Armenian are those proverbs and sayings which are based on an Armenian linguistic form. These are therefore untranslateable, without a gloss, into other languages. Here are to be found various phrases employing rhymes (ditties/ rhymes), cf. the two examples from the previous paragraph and:

Ot ayit meč manni ärev, doxtorin č-es ta pärev ${ }^{8}$

The sentence means: 'If the sun enters your room, you have no need to call a doctor,' cf. the English proverb: An apple a day keeps the doctor away.

Similar in nature, and linked to the Armenian linguistic form, are the 'Salmastian' (Salmast) play on words, e.g.

En c'era parrni, vor et c'ero $k^{h} o$ c'errin $m n a^{9}$

'This is the end of the catch, the other end of which (that) you hold in your hand.'

Commentary. The matter here concerns one of the ends of some object (e.g.: a stick) or, in the metaphorical, the end of some matter. The other end (held in one's hand) is a metaphor for control over a situation which is a condition, for example, to undertake some action. The wordplay is made up of words with a similar pronunciation: c'er 'the end' (East Armenian: [c'ayr]) and c'err 'hand' (with a vibrating ' $r$ ' such as in Spanish $r r$, East Arm. [dzerr]).

\footnotetext{
${ }^{6}$ R. Ohanean, Arrac'ani Salmast..., p. 49 (line 5 from the bottom).

7 Ibidem, p. 49 (line 4 from the bottom).

8 Ibidem, p. 49 (line 8 from the bottom).

9 Ibidem, p. 16 (line 1 from the bottom).
} 
The vast majority of the proverbs are not connected with phonetics but with meaning. That said obviously Armenian proverbs as is the case with the proverbs of other nations are characterised by a conciseness and often are rhythmical in character, connected with the number of syllables in a given word. For phrases of this type should be distinguished from the normal rhythm of speech (people speak 'in prose,' as the hero of Molière's comedy has already remarked with astonishment). It should distinguish itself from the other sections of the utterance so that the recipient of the communique is aware that the interlocutor is saying something not 'from themselves' but they are quoting (!) a known saying in the given culture, one which goes at the given moment with its meaning to the content of the utterance or to the circumstances occurring within a given case, cf. the Polish saying 'o wilku mowa, a wilk tu' with the English 'Talk of the devil, and he is sure to appear.'

We expect proverbs to be, in as far as this is possible, 'beautiful' in terms of their form. This is clearly illustrated by the saying from page 41 :

Xoska mäsäl-ov i sirun ${ }^{10}$

'Sayings adorn speech,' literally: 'Speech is [end $i$ after the second word] beautiful (sirun) thanks to a saying.'

Here there appears (in the instrumental singular) the Arabic word mathal 'example' known to Armenians from the Turkic area (Turkish masal, Azeri masal) and the Iranian (Persian masal). In the glossary to the Salmast dialect the author, Rubik Ohanian, gives for this word the Armenian literary equivalent arrak 'fairytale'.

There appear in Armenian proverbs, as is the case in other languages, various stylistic figures of speech: metaphors, antithesis, parallelism, etc. An important element within the language of proverbs is also humour, visible in many sayings of a jokey character.

$$
* * *
$$

The Armenians are a nation for whom the belief in God played and still plays a huge role. This is illustrated, for example, by the proverb from p. 51 (line 1 from the bottom): Växeci en mart'en, vor či växece Astc'en 'I fear the man who does not fear God.' In the original it is expressed by means of a past tense (vaxeci is 'I had been frightened').

In Armenian proverbs God is the protector of nature, e.g.:

Astc'u paxac'kyärro k'el-a či tani ${ }^{12}$

'The wolf does not take the sheep that God tends' (cf. the Polish proverb 'Strzeżonego Pan Bóg strzeże' [forewarned is forearmed]).

God is the proto-source of morality:

Mart ${ }^{\text {mart }}$ u iresin k-iška, Astvac'sartin ${ }^{13}$

'Man looks at the face (of another man), God - at his heart.'

10 Ibidem, p. 41 (line 3 from the bottom).

11 R. Ohanean, Barracank (barraran)..., p. 100.

12 R. Ohanean, Arrac'ani Salmast..., p. 24 (line 3 from the top).

13 Ibidem, p. 44 (line 2 from the bottom). 
With the meaning 'looks' there occurs the dialect form $k$-iška (in which resides the element known from the word $a c k^{h}$ 'eye') reciprocating in meaning the East Armenian (EArm) nay-um e.

Armenians are proud of the fact that they were the first nation on earth to adopt Christianity as the state religion (the beginning of the $4^{\text {th }}$ century). Nevertheless they can be critical towards their clergy. This can be seen, for example, in the proverb:

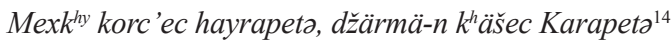

'Sin filled the patriarch, (but) punished was (a man named) Karapet.'

In this proverb there is employed the rhyme: hayrapet ('patriarch') - Karapet. In the meaning of 'punishment' there occurs by means of a borrowing from Turkic or Persian the Arabism džärmä, cf. Arabic jurm, jarima 'crime' > Turkish cereme 'punishment (money), fine', Persian jormâne 'penalty, forfeit, fine'.$^{15}$ Of interest here is the shifting of meaning from the source Arabic word which designates 'crime, felony', to... 'punishment'.

It would be strange if in R. Ohanian's collection of over eight hundred Armenian proverbs there was not a single sentence devoted to the Armenians themselves. This is what they said in Salmast about their own nation (p. 12, line 6 from the top):

Xaya minčev ča-bezari, či nasti ${ }^{16}$

'An Armenian doesn't sit until he is tired' (meaning he is persistent).

This judgement is clearly a positive one. Neutral in character is the saying:

Xaya vor $k^{h}$ axcəna, pärk' endana matk $k^{h}$ in ka peri ${ }^{17}$

'An Armenian when he becomes hungry will recall the carnival.'

Here appears the native Armenian word pärk'endan (the East Armenian literary form barekendan) which is also known to Persians. This constitutes a rare instance of an Armenian borrowing within Persian: the word baryandân is given in the Persian-English dictionary by F. Steingass in the following descriptive translation: 'festivities during the last ten days of Sha'bân; name of the last day of this month; a carnival'. ${ }^{18}$

Proverbs are often universal in character. They concern, among other things, human life in its universality as well as various aspects of the said, for example (in a free translation):

Väv merrni-čə-merrni, parrava hälbät ${ }^{h} k \partial-m e r r n i^{19}$

'A young man dies or doesn't, an old man will die for sure.'

The word hälbäth 'for sure' is an Arabism borrowed from Persian (albatte).

\footnotetext{
${ }^{14}$ Ibidem, p. 4 (line 4 from the bottom).

${ }^{15}$ F. Steingass, A Comprehensive Persian-English Dictionary, London 1892, p. 360.

${ }_{16}$ R. Ohanean, Arrac'ani Salmast..., p. 12 (line 6 from the top).

${ }^{17}$ Ibidem, p. 22 (line 4 from the top).

${ }_{18}$ F. Steingass, op. cit., p. 176.

19 R. Ohanean, Arrac'ani Salmast..., p. 39 (line 1 from the bottom).
} 
A characteristic stylistic figure of speech employed in proverbs are metaphors. Here is an example from Salmast:

Harusti užn inän xoskə džöbi mečə k-əli (where inän means 'and') $)^{20}$

'A rich man's strength and words lie in his pocket.'

The word džöb 'pocket' (an Arabic borrowing taken into the language by means of Turkic cf. the Turkish cep) is here an obvious metaphor for money.

At times proverbs serve to express various psychic states of man, e.g.: amazement over the diversity of phenomena in the world, for example:

Me c'axkhen oca thuyn $i$ šineli, meyun - meyar (where $i$ šineli is 3 . sg. present tense of šinel 'to make') $)^{21}$

'From the same flower an adder will make poison, while a bee - honey.'

In this example one can see not only the diversity but rather the opposition (poison - honey).

Sometime the oppositions concern not only the physical but also psychic matters, e.g.:

Phastikya c'andrr i mor c'angerin, č'oča - xokhun (where $i=$ "is") $)^{22}$

'A small child is a burden for its mother's knees, a large one for her soul.'

Here the matter concerns the problems of upbringing that increase with the course of the years.

Sometimes sentences on the flow of time are embellished with humour, for example:

C'urr axčika xelokh xars k-ali, xelokh xarsa-xelokh kanik;

C'urr kanika c'urr parrav k-əli, c'urr parrava-c'urr merrel ${ }^{23}$

'A stupid girl may become a clever fiancée, a clever fiancée - a clever wife; but a stupid wife will be stupid to old age and will die as a stupid old woman.'

Linguistically of interest in the above example is the adjective c'urr, here clearly employed in the meaning of 'stupid' in direct contrast to xelokh 'clever'. The initial meaning of c'urr was 'bent' (an Armenian synonym being: thekh). The author of this Salmast lexicon of proverbs gives as a dialectical meaning for the adjective c'urr not only thekh but also giž (the East Armenian literary form) 'crazy'. ${ }^{24}$

At some point an anonymous Salmast author noted that: Khyärr marthə erku ankham kə c'əyza 'A deaf man laughs twice'25 (once 'to company', and then again when he knows what's what). In the meaning of 'stupid' (the first word in the sentence) there is employed an adjective borrowed from Persian (kar).

In Armenian folklore there are a lot of proverbs illustrating the clever-stupid opposition of human intellect (as quite possibly elsewhere). Here we have one more example from Salmast (p. 56, line 1 from the bottom):

\footnotetext{
${ }^{20}$ Ibidem, p. 10 (line 7 from the top).

${ }^{21}$ Ibidem, p. 10 (line 3 from the bottom).

22 Ibidem, p. 28 (line 3 from the top).

${ }_{23}$ Ibidem, p. 28 (line 7-8 from the top).

24 R. Ohanean, Barracank (barraran)..., p. 69.

25 R. Ohanean, Arrac'ani Salmast..., p. 28 (line 2 from the bottom).
} 
Äxmäxa matac'el $i$, vor z-inkha xelokh $i$, xelokhn el gyinäli, vor z-inkha äxmäx $i^{26}$ (where gyinäli means: 'he/she knows', the 1. person sg. being gyinäs em 'I know', the 2. person sg. - gyinäs es 'you know). ${ }^{27}$

'A fool thinks he is clever; while a clever person is aware that he himself is deaf' (in the sense: he does not know everything).

In the meaning 'stupid' used here is a word of Arabic origin: $\ddot{a} x m \ddot{x} x(<a h m a q)$.

There are also many proverbs in our material illustrating the differences between the financial state dividing people into rich and poor, for example:

Khyasəbə xaci karot i, harustə - əmen päni ${ }^{28}$

'A poor man yearns for bread, a rich man - for everything.'

One senses here a simultaneous criticism of greed as a fault within the human character.

While criticism of social relations connected with one's material state is to be found within the proverb:

Orenkha harusti xəma y-i, patiškha - khyasəbi ${ }^{29}$

'The law serves the rich, punishments are for the poor.'

With the meaning of 'the poor' many Armenian dialects use a borrowing from Arabic $k^{h y} a s a b$. The Arabic word kāsib has, however, another meaning: that of 'receiving'. In the Persian (kâseb) the range of meanings for this word are the following: 'a gainer, acquirer; one who toils for his bread; an artist, artisan, tradesman; an inquisitor; a receiver of fines'. ${ }^{30}$ The shifting of meaning in this word in the direction of the designation 'poor person' is down to the Azerbaijani (Azeri), in which kasıb is already exclusively 'poor, a poor person'. The Armenian dialect word herein discussed presumably has its origins in Azeri dialects. Though Arabic has here given the basis for its semantic development for (as is given in Baranov's Arabic-Russian Dictionary ${ }^{31}$ ) the word kāsib meant in Iraq a 'petty trader' ('мелкий торговец'). And such an occupation can lead to poverty.

The question of justice or rather its absence is dealt with in the following proverb:

Älurə menkh mayinkh, phäxlävän urišə kyerav ${ }^{32}$

'Flour we ground but the baklava (produced from this flour) is eaten by another.'

The Turkish name baklava (a pastry made from flour, honey and almonds) is in the Armenian dialect of Salmast: $p^{h} \ddot{a} x l \ddot{a} v \ddot{a}$.

With a pinch of salt another proverb talks of a different 'justice':

\footnotetext{
26 Ibidem, p. 56 (line 1 from the bottom).

27 R. Ohanean, Barracank (barraran)..., p. 21.

28 Idem, Arrac'ani Salmast..., p. 5 (line 8 from the top).

29 Ibidem, p. 6 (line 6 from the top).

30 F. Steingass, op. cit., p. 1004.

31 Х.К. Баранов, Арабско-русский словарь, Москва 1976, р. 686.

32 R. Ohanean, Arrac'ani Salmast..., p. 7 (line 4 from the top).
} 
Phalav utela lav i, hama me or mer tuna me or c'er ${ }^{33}$

'The eating of pilau rice (together) is a good thing, but (let's do it) once at our place and once at yours.'

Irony also rings through the following maxim:

Me thähär oxnekhy $k a$, vor aneskhyen phis $i^{34}$

'There are such blessings which are worse than curses,' cf. the English 'kiss of death'.

Many proverbs criticise human faults, for example a tendency to slander, garrulousness, laziness. Some of this criticism is expressed through comparison, e.g.:

Thari karrac'a ka-lavana, lezvi kac'ac'a či lavana (where karrac'< katrac') ${ }^{35}$

'A wound inflicted by a sword heals, but being bitten by the tongue does not.'

Xoska vor ka rezini naman $i$, iš $k^{h}$ an $k^{h y} \ddot{a}$ šes, kə-yerkənna ${ }^{36}$

'Someone's talk can be at times like a rubber band: the more someone stretches it (talk), the more drawn it becomes.'

'Rubber band' is here rendered by the Russian borrowing rezin $(<$ резина).

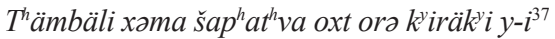

'For an idler every day of the week is Sunday.'

The word $t^{h} \ddot{a} m b \ddot{l} l$ is a borrowing from the Persian tambal 'lazy.'

The difficulties connected with discretion are reflected in the following sentence:

Mart ${ }^{h}$ xəma erku tari petk ${ }^{h}$ i zurrcal sovri, vacun tari el, vor lezun atəmk $k^{h}$ eri iteva paxi $i^{38}$

'A child needs two years to learn how to speak, while an adult sixty years to learn how to keep his tongue to himself.'

Garrulousness is aided by excessive alcohol:

$K^{y}$ inin nes matav, sarra tus $k i-k^{y} a^{39}$

'Where there is wine, secrets emerge.'

'Secret' is here expressed by the Arabism sarr ( < sirr), which appeared in the Armenian Salmast dialect by means of Persian (serr).

Given that human faults are being reproached it follows to recommend to people to follow virtues instead, for example gratitude, hospitality:

Әmmen ank $k^{h}$ am xəndzor $k^{h}$ ayelun, c'arr təngoyin mit ärä! ${ }^{40}$

'Whenever you take an apple from a tree, think who planted it.'

\footnotetext{
33 Ibidem, p. 35 (line 8 from the top).

${ }^{34}$ Ibidem, p. 39 (line 5 from the bottom).

35 Ibidem, p. 12 (line 3 from the bottom).

36 Ibidem, p. 52 (line 8 from the bottom).

37 Ibidem, p. 14 (line 7 from the bottom).

38 Ibidem, p. 56 (line 4 from the bottom).

39 Ibidem, p. 47 (line 1 from the top).

40 Ibidem, p. 31 (line 1 from the bottom).
} 
Here is a piece of morally positive advice:

Tark' eci xeyräthin thamah ärä, unecvac' $k^{h}$ in č $e^{4^{41}}$

'Envy a neighbour's kindness and not his fortune!'

Here we have two Arabisms: xeyrät 'goodness' < xayra(t) and $t^{h}$ amah 'greed' $(<$ tama $)$ in the compound verb $t^{h}$ amah änel 'to envy'.

At times the spur for goodness is threatening in character, for example:

Astc'u konayin vor tun čz-thoynes, mekat erku či tärrna ${ }^{42}$

'If you do not allow into your home God's guest (sent from), then your one will not become two' (hence: you will not prosper).

Here the meaning of 'guest' in the sentence is conveyed by the Turkic word kona, which in present-day Turkish, written konak, has meanings linked to giving hospitality: '1. halting place; stage; inn, 2. a day's journey, 3. mansion; residence; government house, 4. (archaic) guest, temporary visitor...' ${ }^{43}$ In Azerbaijani gonag is a 'guest', and so from this language has arrived the authenticated word in the Armenian Salmast dialect.

Yet some of the advice here proclaimed could arouse moralistic reservations, e.g. (p. 23, line 8 from the bottom):

Me c'erra, vor činäs karrel, petk ${ }^{h} e$ pak ${ }^{h}$ es tanes kalxit (where karrel < katrel 'to cut off') $)^{44}$

'The hand you cannot cut off, kiss and place on the head (as a sign of submissiveness).'

Does this not smack of praising... hypocrisy?

'Negative' pieces of advice are warnings. As an example:

$K^{y}$ eti meč ärräč mi ənci, mešäyi meč itev mi mna $4^{45}$

'In the river do not forge against the current (for it is dangerous), but in the forest do not remain at the rear (for you will get lost)!'

Armenians use in Salmast the word mešä for forest. This is a borrowing from the Azerbaijani mešz (of the self same meaning and the very same pronunciation).

A warning may sometimes be 'descriptively' expressed without the particle 'no/not', for example:

Ärräč p $p^{h}$ axnoyin ka-parrnen ${ }^{46}$

'Whoever escapes first will be caught the first' (conclusion: don't escape first!).

As far as the strength of evil, which one should never underestimate, recourse is made in the following proverbs:

Harama vor ekav, halalin el xeta ka-tani ${ }^{47}$

'Evil will carry away with it good.'

\footnotetext{
41 Ibidem, p. 44 (line 6 from the top).

42 Ibidem, p. 32 (line 2 from the bottom).

${ }^{43}$ New Redhouse Turkish-English Dictionary, İstanbul 1968, p. 673.

44 R. Ohanean, Arrac'ani Salmast..., p. 23 (line 8 from the bottom).

45 Ibidem, p. 40 (line 4 from the bottom).

46 Ibidem, p. 28 (line 1 from the bottom).

47 Ibidem, p. 46 (line 4 from the bottom).
} 
As well as:

$X o k^{h} u \check{c} a r \partial t^{h} O n \partial \check{c} i$ čäp $p^{h} i^{48}$

'The evil of the human soul cannot be measured.'

In the first of these sentences 'evil' and 'good' have been conveyed by means of the Arabic words connected to Islamic culture: haram and halal (Arabic: harām, halāl). While in the second 'evil' has been rendered through the native word čarathon, which is an abstract noun formed from the adjective čar 'evil/bad' (cf. the East Armenian literary: čarut'yun 'evil').

The wisdom contained in Salmast proverbs incorporates the difficulties connected with acting in accordance with moral requirements:

Aselan amot $^{h} i$, časela - mexk $k^{h y 49}$

'Sometimes saying something encompasses shame, yet not saying this would be a sin.'

$* * *$

The role played by experience finds reflection in the following proverb:

Yezan lava lac'i tak mälam $k-\ddot{a} n i^{50}$

'Whether an ox is good will only materialise under the yoke' (i.e., when it starts to work).

The penultimate word is an Arabism (ma 'lûm 'known') borrowed by the Armenians through the medium of Persian or Azerbaijani.

A practical take on the world is encapsulated in the following proverb:

Xäzär xat došägy unenas, meki vrä $k \partial-k^{h y} n e s^{51}$

'Even though you have a thousand mattresses, you are only going to sleep on one.'

The term for 'mattress' is here rendered by the Turkish word döşek (or rather its Azerbaijani equivalent: döşək, as is borne out by the phonetics).

The following observation finds parallels in a host of languages:

Nälbändi dzin votpepuyk $k$-oli $i^{52}$

'A farrier's horse goes unshod.'

For a farrier, similarly to other craftsmen is so busy making a living that he has no time to shoe his own horses. Here the meaning for 'farrier' is taken by a word of Arabic-Persian etymology nä l-bänd.

The following proverb talks of the difficulties of another profession (that of a nurse):

Lav $i$ xavand ales, $k^{h} \ddot{a n t} t^{h} i$ xavand paxes ${ }^{53}$

'It's better to be ill yourself than care for the sick.'

Protest would surely be heard from genuine male and female nurses, those with a 'vocation'.

\footnotetext{
48 Ibidem, p. 48 (line 3 from the top).

49 Ibidem, p. 43 (line 2 from the top).

50 Ibidem, p. 29 (line 6 from the bottom).

51 Ibidem, p. 48 (line 1 from the bottom).

52 Ibidem, p. 10 (line 5 from the top).

53 Ibidem, p. 10 (line 1 from the bottom).
} 
Belief in man's immense possibilities are expressed by the saying on page 18, line 7 from the bottom:

Enenc pän č̀-ka, vor mart ${ }^{h}$ uzi č-inä änel ${ }^{54}$

'There isn't anything man couldn't make if he wanted.'

Earlier people had, as is known, much greater contact with animals than is the case today. Consequently it comes as no surprise to learn of the frequency with which animals appear in the proverbs from Salmast. Some are quite probably merely practical observations, like, for example:

$T^{h}$ ex tun, dzin el čavkarelov $k-e t^{h} a^{55}$

'A horse runs faster the nearer home.'

Yet many more are metaphorical in character, where man lurks beneath the image of an animal, e.g.:

Sus dziyan thä $p^{h} \ddot{u} g^{y}$ ə pind $k$-əli $i^{56}$ (for $t^{h} \ddot{a} p^{h} \ddot{u} g^{y}$ compare M. Ye. Asatrian's book) $)^{57}$

'Kicking a silent horse can be risky' compare the Polish 'z cicha pęk'.

Obviously certain classification criteria overlap, for example:

Sirac'a en či, vor sirun $i$, sirun $i$ en, vor sirac'n $i^{58}$

'Beloved is not the one who is beautiful; beautiful is the one who is loved.'

This proverb talks of love. Though from a formal point of view it constitutes a pair of contradictions. And in addition there is at work in the Armenian a play on words: in Armenian sir-ac' 'beloved' and sir-un 'beautiful' (from the self same verbal root, cf. sir-el to love'). Here it follows to know that the Armenian language, in a similar way to Persian, does not have grammatical gender (even in personal pronouns, cf. the English: he - she, which correspond to the Armenian $n a$ and Persian $u)$.

I will conclude this brief thematic overview of Armenian proverbs from Salmast with sayings whose meaning is not clear to me:

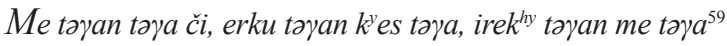

'One boy is not yet a boy, two boys are half a boy; only three boys are a true boy.'

\footnotetext{
${ }^{54}$ Ibidem, p. 18 (line 7 from the bottom).

55 Ibidem, p. 9 (line 2 from the bottom).

56 Ibidem, p. 1 (line 1 from the bottom).

${ }^{57}$ M.Ye. Asatryan, Urmiayi (Xoyi) barbarro, Yerevan 1962, p. 215.

58 R. Ohanean, Arrac'ani Salmast..., p. 42 (line 6 from the bottom).

59 Ibidem, p. 55 (line 1 from the top).
} 
Possibly here an allusion is being made to the folk notions clear for a "native speaker' of the Armenian dialect of Salmast yet not obvious at all to an outsider.

Or:

Mart a c'ov i, kanika g'ol ${ }^{60}$

'A husband is a sea, while a wife - a lake.'

Quite honestly I am at a loss as to what is happening here, despite having been married now for half a century. For the word 'sea' here is employed the native word c'ov, for 'lake' - the Turkic göl and not the native lič'. In Armenian dialects, as opposed to the two literary variants of the language (East Armenian, West Armenian) - not to mention the Grabar (Old Armenian) of the $5^{\text {th }}$ century - there appear a significant number of borrowings from the languages of Islam surrounding the Armenians: from Arabic, Persian and Turkic (Azerbaijani).

Many of the Armenian proverbs from Iran have presumably Persian and Turkic parallels. Here it would be worth conducting a comparison.

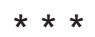

At the end I would like to thank Mr Guy Torr for having translated my article from Polish and having enriched it with some English parallels.

$* * *$

A version of this article enhanced by a greater number of examples has appeared in Polish in the quarterly "Biuletyn Ormiańskiego Towarzystwa Kulturalnego", no. $86 / 87$ of 2016 .

\section{Bibliography}

Asatryan M.Ye., Urmiayi (Xoyi) barbarro, Yerevan 1962.

New Redhouse Turkish-English Dictionary, İstanbul 1968.

Ohanean R., Arrac'ani Salmast gawarri barbarrov, Tehrân 2012.

Ohanean R., Barracank (barraran). Salmasti barbarr, Tehrân 2012.

Steingass F., A Comprehensive Persian-English Dictionary, London 1892.

Tanalanyan A., Arrac'ani, Yerevan 1960.

Taribyan A., Hay barbarragituthyun, Yerevan 1953.

Баранов Х.К., Арабско-русский словарь, Москва 1976.

${ }^{60}$ Ibidem, p. 22 (line 3 from the bottom). 